\title{
Geochemistry and Boron Isotopic Ratios of Tourmaline from granitic pegmatites in East Qinling: Implications for rare metal exploration
}

YONGGANG FENG, TING LIANG, MENGXI WANG AND XIJUAN TAN

Chang'an University

Presenting Author: ygfeng@chd.edu.cn

Tourmaline is a common igneous mineral in granitic pegmatites and an excellent container for various elements. The Danfeng-Shangnan-Guanpo region in the Eastern Qinling Orogen is one of the important pegmatite provinces in China, with the majority of Li pegmatites being confined to Guanpo. The pegmatites in this region show a distinct regional zonation away from the Huichizhi granite, the largest pluton in the same region. Previous studies have indicated that the pegmatites mainly formed at 418 - $390 \mathrm{Ma}$. In this study, we systematically sampled the granitic pegmatites from five localities following the regional zonation of the pegmatites and investigated the compositional variations of igneous tourmalines that belong to same species to see whether tourmaline chemistry can serve as an exploration vector for Li pegmatites. The horizontal distances toward the Huichizi granite increase from Caijiagou (CJG) to Fengzhuang (FZ) to Shuangfengcun (SFC) to Fengyuan (FY) to Nianpan (NP).

All the analyzed tourmalines from both Li mineralized and barren pegmatites are schorl of an igneous origin. The schorl from the CGJ Li pegmatites show the highest $\mathrm{Li}, \mathrm{Mn}$, and $\mathrm{Zn}$ concentrations. The Na concentrations of the schorl from all the studied pegmatites are consistent. Compared to the barren pegmatites, the schorl from the CGJ Li pegmatites contains extremely low rare earth elements. Overall, the B isotopic ratios show a distinct correlation with the Li concentrations of the schorl from the studied pegmatites. From barren to $\mathrm{Li}$ mineralized pegmatites, the $\mathrm{B}$ isotopic ratios evolve toward more negative values, with the schorl from the CGJ Li pegmatites showing the lowest values $\left(\delta^{11} \mathrm{~B}_{\mathrm{NIST} 951}=\sim-18.0 \%\right)$. However, extensive hydrothermal alteration or fluid exsolution that has happened to the barren pegmatites strongly influence the variation of $\mathrm{B}$ isotopic ratios, causing a large scattering of $\delta^{11} \mathrm{~B}_{\mathrm{NIST} 951}$ values.

[1] Yuan et al. (2018), Lithos. 